\title{
Antagonistic yeasts competes for iron with winter wheat stem base pathogens
}

\author{
Urszula Wachowska $\cdot$ Justyna Borowska
}

Received: 15 May 2014 / Accepted: 20 August 2014 / Published online: 10 September 2014

(C) The Author(s) 2014. This article is published with open access at Springerlink.com

\begin{abstract}
Aureobasidium pullulans and Sporobolomyces roseus are a saprotrophic yeasts fungi commonly found on the leaves of winter wheat and on wheat kernels. The objective of this study was to compare the inhibitory effects of two species of yeasts fungi, Aureobasidium pullulans var. pullulans (de Bary) G. Arnaud and Sporobolomyces roseus Kluyver \& van Niel, on the causal agents of stem base diseases, Rhizoctonia cerealis v. d. Hoeven, Gaeumannomyces graminis (Sacc.) Arx \& D. Olivier, Helgardia herpotrichoides (Fron) Crous \& W. Gams, Fusarium oxysporum (Schlecht) Snyd. et Hans.) and Fusarium culmorum (W. G. Smith). A. pullulans showed stronger inhibitory activity than $S$. roseus. Among the 70 A. pullulans isolates tested in the study, 25 were capable of suppressing the colony growth of $R$. cerealis under in vitro conditions. This is the first study to show that $A$. pullulans competes for iron with stem base pathogens, in particular with fastgrowing $R$. cerealis and F. culmorum. Under greenhouse conditions, $A$. pullulans protected winter wheat seedlings against infection caused by $F$. culmorum, from two to four times compared with the control, and its protective effect was determined by the infection susceptibility of wheat cultivars and the time interval between the application of A. pullulans and inoculation with F. culmorum.
\end{abstract}

Urszula Wachowska is phytopathologist and mycologist working at the Warmia and Mazury University in Olsztyn on the professor position. Her research field is the integrated and biological protection of cereals and some horticultural plants, mainly strawberries.

U. Wachowska $(\bowtie) \cdot$ J. Borowska

Department of Phytopathology and Entomology,

University of Warmia and Mazury,

10-720 Olsztyn, ul. Prawocheńskiego 17,

Olsztyn, Poland

e-mail: urszula.wachowska@uwm.edu.pl
Keywords Siderophores $\cdot$ Aureobasidium pullulans . Winter wheat $\cdot$ Stem base pathogens

\section{Antagonistische Hefen konkurrieren mit Winterweizenhalmbasis-Pathogenen um Eisen}

Zusammenfassung Aureobasidium pullulans und Sporobolomyces roseus sind saprotrophische Hefen, die auf Weizenblättern und -Korn weit verbreitet vorkommen. Das Ziel der Studie war es, die inhibitorische Wirkung von zwei Arten von Hefen Aureobasidium pullulans var. pullulans (de Bary) G. Arnaud und Sporobolomyces roseus Kluyver \& van Niel mit den Halmbasis-Pathogenen: Rhizoctonia cerealis VD Hoeven, Gaeumannomyces graminis (Sacc.) Arx \& E. Olivier, Helgardia herpotrichoides (Fron) Crous \& W. Gams, Fusarium oxysporum (Schlecht) Snyd. und Hans, Fusarium culmorum (S. W. Smith) zu vergleichen. A. pullulans wies eine stärkere inhibitorische Wirkung als $S$. roseus auf. Unter den 70 getesteten $A$. pullulans Isolaten haben 25 unter in vitro Bedingungen den Zuwachs der Kolonie $R$. cerealis eingeschränkt. Dies ist das erste Anzeichen, dass den Beweis dafür liefert, dass A. pullulans mit den Halmbasis-Pathogenen, insbesondere mit den schnell wachsenden Arten, wie $R$. cerealis und $F$. culmorum, ums Eisen konkurriert. Unter Gewächshausbedingungen waren die mit $A$. pullulans behandelten und mit F. culmorum inokulierten Winterweizen-Sämlinge im Vergleich zur Kontrolle zwei- bis viermal weniger befallen. Die Schutzwirkung von A. pullulans war von der Empfindlichkeit der Weizensorten und dem Zeitintervall zwischen der Anwendung von A. pullulans und der Inokulation von F. culmorum abhängig. 
Schlüsselwörter Siderophore $\cdot$ Aureobasidium

pullulans $\cdot$ Winterweizen $\cdot$ Halmbasis-Pathogenen

\section{Introduction}

The cereal stem base disease complex comprises eyespot (teleomorph: Oculimacula yallundae (Wallwork \& Spooner) Crous \& W. Gams, Oculimacula acuformis (Boerema \& Hamers) Crous \& W. Gams anamorph: Helgardia yallundae (Nirenberg) Crous \& W. Gams, Helgardia acuformis (Nirenberg) Crous \& W. Gams), Fusarium foot rot (Fusarium culmorum (W. G. Smith), Fusarium avenaceum (Fr.) Sacc., Fusarium oxysporum (Schlecht) Snyd. et Hans.), sharp eyespot (teleomorph: Ceratobasidium cereale Murray \& Burpee, anamorph Rhizoctoniacerealis v. d. Hoeven) and take-all (Gaeumannomyces graminis (Sacc.) Arx \& D. Olivier) (Ray et al. 2006). Each year, stem base diseases cause a substantial decrease in total wheat yield, due to a reduced number of spikes per unit area and poor grain filling (Ray et al. 2006). The above diseases have proven to be difficult to control. Effective fungicide treatments have been developed only for pathogens of the genus Helgardia (Maliński 2008) and the species G. graminis (Bateman et al. 2006). The applied methods do not provide complete disease control in all cases, especially that some pathogens can evolve fungicide resistance (Frac Code list (FRAC) 2009). Therefore, alternative management strategies need to be developed to protect small grain cereals against stem base diseases.

Biological control offers a viable alternative for the management of fungal diseases, including stem base diseases. Attempts have been made to use bacteria and yeasts fungi as biocontrol agents against wheat pathogens during the growing season (Kita et al. 2004; Wachowska et al. 2003; Zhang et al. 2007; Liu et al. 2011) and throughout the grain storage period (Druefors and Schnürer 2004). Commercial biocontrol agents containing yeasts fungi, such as Boni Protect $^{\mathrm{TM}}$ (Aureobasidium pullulans, DSM 14940 and DSM 14941 strains, Bio-ferm, Austria) are widely used today (Holb and Kunz 2013). Since biocontrol agents and fungicides have a different mechanism of action, their efficacy is difficult to compare. Beyond a doubt, biocontrol agents are environmentally-friendly and have a broad spectrum of activity against pathogenic species, including those difficult to control with fungicides (Zhang et al. 2007). Efforts made to date have focused on the use of selected bacterial strains as antagonists of take-all in winter wheat caused by $G$. graminis (Liu et al. 2011). The control of stem base pathogens, in particular in early stages of seedling development and in organic farming systems where the use of chemical crop protection agents is limited, has been insufficiently investigated.
Aureobasidium pullulans (de Bary) G. Arnaud is a saprotrophic, polymorphic yeast-like fungus. The inhibitory effect of this species on pathogens and plants has been widely discussed (Ippolito et al. 2000; Schena et al. 2003; Raspor et al. 2010), yet its exact mechanism of action remains unproven. A. pullulans is commonly observed on the surface and in the tissues of crops. It produces lytic enzymes, such as chitinase and beta-1,3-glucanase, which suppress the growth of phytopathogens (Vero et al. 2009; Gaur et al. 2010). A. pullulans can also produce aureobasidins, polypeptide substances showing fungicidal action, which inhibit the growth of species of the genus Aspergillus (Prasongsuk et al. 2013). Aureobasidins are a family of cyclic depsipeptide antibiotics with 18 known derivatives (aureobasidin A to R) that differ in their amino acid composition (Prasongsuk et al. 2013; Ikai et al. 1991) and are known to inhibit inositol phosphoacrylamide synthase, a key enzyme for fungal sphingolipid synthesis (Zhong et al. 2000).

One of the mechanisms of biological disease control in crop plants involves competition for iron between pathogens and antagonistic microorganisms (Vero et al. 2009). Iron is required in a number of fungal growth processes such as the synthesis of deoxynucleotides, respiration, tricarboxylic acid cycle and the synthesis of amino acids, lipids and sterols (Philpott 2006). Under iron deficiency, most microorganism produce low molecular weight, iron-chelating ligands - siderophores (Wang et al. 2009).

The aim of this study was to compare the inhibitory effects of selected yeasts fungi on the causal agents of stem base diseases in winter wheat under in vitro and under greenhouse conditions.

\section{Material and Methods}

Isolates of yeasts fungi used under in vitro conditions.

The activity of selected isolates of two yeasts fungal species, Aureobasidium pullulans var. pullulans and Sporobolomyces roseus, was determined in the study (Table 1). $S$. roseus isolates were obtained from the leaves of winter wheat cv. Tonacja (List of Agriculture Cultivars 2008). Fifteen leaf segments, $1 \mathrm{~cm}$ in length, were placed in $250 \mathrm{ml}$ flasks filled with $15 \mathrm{ml}$ sterile water. A. pullulans isolates were obtained from the grain of winter wheat $\mathrm{cv}$. Tonacja grown in Tomaszkowo $\left(53^{\circ} 42^{\prime} \mathrm{N}, 20^{\circ} 26^{\prime} \mathrm{E}\right)$, protected and not protected with fungicides, and from winter wheat cv. Olivin (List of Agriculture Cultivars 2008) grown in Bałcyny $\left(53^{\circ} 35^{\prime} \mathrm{N}, 19^{\circ} 51^{\prime}\right)$, both localization in NE Poland (Table 1). Grain samples of $10 \mathrm{~g}$ were placed in $250 \mathrm{ml}$ flasks filled with $90 \mathrm{ml}$ sterile water. Flasks containing leaves or grain were shaken for $30 \mathrm{~min}$ (180 rpm) using a laboratory shaker, (358-S, Elpin +, Poland). The resultant suspensions, in the amount of $0.1 \mathrm{ml}$, were transferred to Petri dishes 
Table 1 Origin of $A$. pullulans epiphytic isolates obtained from winter wheat kernels treated with various fungicides

\begin{tabular}{|c|c|c|}
\hline Isolate code & $\begin{array}{l}\text { Cultivar of } \\
\text { winter wheat }\end{array}$ & Chemical treatments \\
\hline Ap $1 \div 11$ & Tonacja & $\begin{array}{l}\text { Amistar } 250 \mathrm{SC} \text { ( } 25 \% \text { azoxystrobin }) \text {, } \\
\text { Syngenta Crop Protection, Poland }\end{array}$ \\
\hline Ap $12 \div 22$ & Tonacja & $\begin{array}{l}\text { Mirage } 450 \text { EC ( } 45 \% \text { prochloraz), } \\
\text { Makhteshim Agan, Poland }\end{array}$ \\
\hline Ap $23 \div 34$ & Tonacja & without treatment \\
\hline Ap $35 \div 45$ & Olivin & $\begin{array}{l}\text { Siarkol Extra } 80 \text { WP ( } 80 \% \text { sulfur), } \\
\text { Organika-Sarzyna Chemical Works, } \\
\text { Poland }\end{array}$ \\
\hline Ap $39 \div 55$ & Tonacja & $\begin{array}{l}\text { Karben } 500 \mathrm{SC} \text { ( } 50 \% \text { carbendazim), } \\
\text { Bayer, Poland }\end{array}$ \\
\hline Ap $56 \div 70$ & Tonacja & $\begin{array}{l}\text { Bumper } 250 \text { EC ( } 25 \% \text { propiconazol), } \\
\text { Makhteshim Chemical Works, Israel }\end{array}$ \\
\hline
\end{tabular}

(9 $\mathrm{cm}$ diameter, $0.1 \mathrm{ml}$ in volume Margomed, Poland, and cooled Martin medium was poured into the dishes (Martin 1950). The colonies of yeasts fungi were transferred onto agar slants, and were identified to the species level by microscopic (Nikon E 200, Japan) methods (Barnett et al. 2000; Kurtzman et al. 2011) and to the variety level based on the ITS 1-5.8SrDNA-ITS 2 sequence regions by the method described in a previous study (Wachowska et al. 2013).

Isolates of pathogens causing stem-base diseases.

The isolates of Helgardia herpotrichoides, Rhizoctonia cerealis, Gaeumannomyces graminis,Fusarium culmorum and $F$. oxysporum were obtained from the stem bases of winter wheat $\mathrm{cv}$. Tonacja. In order to obtain the colonies of the studied phytopathogens, infected stem base segments were cultured on PDA medium. F. culmorum, F. oxysporum, $G$. graminis and $H$. herpotrichoides were identified based on sporulation characteristics, and the number of nuclei in hyphal cells was determined for $R$. cerealis. The taxonomic affinity of the fungus $G$. graminis was confirmed by a pathogenicity test performed on wheat seedlings.

Activity of yeasts fungi under in vitro conditions.

At the first stage of the experiment, the inhibitory activity of two yeasts fungal species, $S$. roseus and A. pullulans var. pullulans, against the phytopathogens $F$. culmorum, F. oxysporum, G. graminis, $H$. herpotrichoides and $R$. cerealis was tested. A total of $70 \mathrm{~A}$. pullulans isolates and one $R$. cerealis isolate were selected for further analyses. The antagonistic activity of all isolates was determined on Petri dishes. Five mm disks overgrown with seven-day-old pathogenic cultures were placed in the centre of Petri dishes. Fortyeight-h-old cultures of antagonistic yeast-like fungi were transferred to Petri dishes and were placed at a distance of $2 \mathrm{~cm}$ from the disks, on both sides of pathogen colonies. The microbial activity of yeast-like fungi was assessed after four days of growth. A measure of inhibitory activity was the elliptical shape factor calculated by dividing the length of the short (minor) axis by the length of the long (major) axis of the ellipse circumscribed around the colony. The fungal isolates in whose presence the colonies of $R$. cerealis assumed the elongated of an ellipse (elliptical shape factor -ESF-below 0.69) were considered to be biologically active.

Competition for iron between A. pullulans and pathogens.

The cultures of $A$. pullulans, F. culmorum, G. graminis, $H$. herpotrichoides and $R$. cerealis were placed on PDA medium containing different concentrations of iron chloride $\left(\mathrm{FeCl}_{3}\right)(0,10,100$ and $500 \mu \mathrm{M})$, according to the method proposed by Vero et al. (2009). Agar disks overgrown with two-week-old pathogenic cultures were placed on Petri dishes, and A. pullulans cells were placed within a distance of $3 \mathrm{~cm}$. After six days of incubation, the surface area of pathogenic colonies was measured using the ImageJ (v. 1.44n) application (Rasband 2011).

Survival rates of $A$. pullulans at different temperatures.

The suspensions of $A$. pullulans isolates were cultured on solid PDA (Merck). $0.1 \mathrm{ml}$ samples of A. pullulans at a concentration of $10^{4}$ cells were placed in Petri dishes and incubated at $4,14,24$ and $37^{\circ} \mathrm{C}$. The colonies were counted after four days of growth.

Susceptibility of winter wheat seedlings treated with the isolates of A. pullulans to infections caused by F. culmorum.

The biological activity of the A. pullulans isolate (denoted by the symbol Ap 6) was determined on the seedlings of winter wheat cvs. Roma and Sakwa (List of Agriculture Cultivars 2008). An isolate of F. culmorum characterized by the highest pathogenicity was selected among isolates obtained from the stem bases of winter wheat. Twenty surface-disinfected kernels were sown in pots with a diameter of $12 \mathrm{~cm}$, filled with garden soil mixed with sand at the 1:1 ratio. The pots were placed in a growth chamber, and seedlings were watered with Hoagland's solution (Hoagland and Arnon 1950). The plants were grown at relative air humidity of $70-80 \%$, temperature of $23( \pm 1)^{\circ} \mathrm{C}$ during the day and $16( \pm 1)^{\circ} \mathrm{C}$ at night, with a $12 \mathrm{~h} \mathrm{light} / 12 \mathrm{~h}$ dark photoperiod. After two weeks, yeast fungi at a concentration of $10^{6}-10^{7}$ cells per $\mathrm{ml}$ were applied onto the leaves. Agar disks with a diameter of $10 \mathrm{~mm}$ overgrown with seven-day-old mycelium of $F$. culmorum were transferred to the coleoptiles of wheat seedlings on the medium surface. Inoculation with the pathogen was carried out 24, 48 and $96 \mathrm{~h}$ after the application of the A. pullulans isolate onto the leaves. Seedlings inoculated with the pathogen and not treated with a cell suspension of yeasts fungi, and seedlings not inoculated with the pathogen and treated with a cell suspension of $A$. pullulans served as control samples. The infection rate of winter wheat seedlings was assessed two weeks after inoculation with the pathogen. The health status of seedlings was evaluated on a four-point scale. Seedlings with single, small-sized spots on the leaf sheaths were considered to be mildly infected $\left(1^{\circ}\right)$, seedlings with lesions covering up to $50 \%$ surface area were considered to be moderately infected $\left(2^{\circ}\right)$, and seedlings with lesions covering 
Table 2 Biocontrol activity of yeast-like fungi (S. roseus - Sr and A. pullulans-Ap6) expressed as values of elliptical shape factor. SE value are given in brackets

\begin{tabular}{lllllll}
\hline Species/isolate & Pathogens & \multicolumn{5}{l}{} \\
\cline { 2 - 7 } & G. graminis & F. oxysporum & F. culmorum & R. cerealis & O. herpotrichoides & Mean \\
\hline Control & $0.94^{b-e}$ & $0.96^{d e}$ & $0.99^{d e}$ & $1.00^{d e}$ & $0.94^{a-d}$ & $0.98^{i}$ \\
& $( \pm 0.05)$ & $( \pm 0.01)$ & $( \pm 0.23)$ & $( \pm 0.01)$ & $( \pm 0.11)$ & $0.95^{a-d}$ \\
Sr & $0.83^{a b c}$ & $0.77^{a-e}$ & $0.94^{b-e}$ & $0.63^{a-d}$ & $( \pm 0.05)$ \\
& $( \pm 0.01)$ & $( \pm 0.03)$ & $( \pm 0.03)$ & $( \pm 0.04$ & $( \pm 0.02)$ & $( \pm 0.06)$ \\
Ap6 & $0.61^{a b c}$ & $0.82^{a-e}$ & $0.84^{a b c}$ & $0.59^{a b}$ & $0.73^{a-e}$ & $0.71^{k}$ \\
& $( \pm 0.01)$ & $( \pm 0.03)$ & $( \pm 0.02)$ & $( \pm 0.06)$ & $( \pm 0.06)$ & $( \pm 0.04)$ \\
Mean & $0.82^{x y}$ & $0.88^{y}$ & $0.89^{y}$ & $0.71^{x}$ & $0.77^{x y}$ & $( \pm 0.04)$ \\
& $( \pm 0.12)$ & $( \pm 0.04)$ & $( \pm 0.09)$ & $( \pm 0.10)$ &
\end{tabular}

Values followed by the same letter do not differ significantly according to SNK test at $p<0.05$. $a-e$-for interaction, $i-k$-for mean values for antagonistis, $x-y$ - for mean values for pathogens

more than $50 \%$ surface area were considered to be severely infected $\left(3^{\circ}\right)$. Dying out seedlings were considered to be most severely infected $\left(4^{\circ}\right)$. The average infection index was calculated based on the severity of symptoms. The experiment was conducted twice, in three replications.

Statistical analysis.

The data were verified statistically by analysis of variance (ANOVA), using Statistica 9.0 software (StatSoft, Inc. 2009). The significance of differences between means in laboratory analyses was estimated by the Student-Newman-Keuls test.

\section{Results}

Numerous populations of $S$. roseus and A. pullulans were isolated from the leaves of winter wheat cv. Tonacja. The inhibitory activity of both fungal species was compared at the first stage of the study. S. roseus was isolated from leaves, and its inhibitory effect on the causal agents of stem base diseases was unsatisfactory, particularly with respect to F. culmorum (Table 2). The elliptical shape factor calculated for this phytopathogen in the presence of $S$. roseus reached 0.94 , and it did not differ significantly from the values reported for the control treatment.

A. pullulans var. pullulans formed characteristic, fast growing cream-colored colonies. Under in vitro conditions, the selected isolate of $A$. pullulans (Ap 6) showed a strong suppressing effect on the tested phytopathogens, in particular R. cerealis and G. graminis (Table 2). The elliptical shape factor of $R$. cerealis colonies in the presence of the antagonistic species reached 0.59 , and it was significantly lower than in the control treatment. At such a value of the shape factor, at least $8 \mathrm{~mm}$ inhibition zones were formed between the pathogen and the antagonist colonies. The pathogen colonies became more elliptical in shape and the values of their shape factors decreased along with an increase in the number and activity levels of inhibitors produced by the antago- nistic species. $R$. cerealis was most sensitive to the presence of the yeast fungus. The antagonistic activity of $A$. pullulans against $G$. graminis was slightly weaker. Since the elliptical shape factor of this pathogen was 0.61 , the inhibitory effect exerted by $A$. pullulans was considered satisfactory. The colony development of the other tested pathogenic species was suppressed to a low degree. In the presence of $A$. pullulans, the elliptical shape factors of $F$. culmorum and $H$. herpotrichoides reached 0.84 and 0.73 , respectively. Therefore, the activity of the antagonistic species was found to be relatively weak (Table 2 ).

The inhibitory activity of $70 \mathrm{~A}$. pullulans isolates obtained from wheat kernels against $R$. cerealis was determined at the second stage of the experiment. Only $25 \mathrm{~A}$. pullulans isolates (35.71\%) inhibited the growth of $R$. cerealis (Fig. 1). Most of those isolates were obtained from the grain of winter wheat cv. Tonacja, seven isolates came from unprotected plants, and nine isolates were obtained from wheat plants treated with propiconazole (Table 1). Other active strains were isolated from the kernels of wheat plants treated with products containing carbendazim, prochloraz and azoxystrobin.

One A. pullulnas isolate (Ap 6), was selected for further analyses. An attempt was made to investigate its mechanism of action in plant pathogens and crops. This isolate is safe to use as it is able to grow only in a narrow temperature range. The optimum growth temperature of the above isolate on the PDA medium (Merck) is $24^{\circ} \mathrm{C}$, and it is unable to grow at 4 and $37^{\circ} \mathrm{C}$.

The analyzed pathogen colonies developed in Petri dishes in the presence of $A$. pullulans. The larger surface areas of the tested pathogen colonies in Petri dishes containing $500 \mu \mathrm{M}$ ferrous chloride were an indirect indicator of the degree of competition for iron between the pathogens and A. pullulans in the medium with lower levels of $\mathrm{Fe}^{3+}$ ions. A faster growth rate of $F$. culmorum, $R$. cerealis and $H$. herpotrichoides colonies was observed in agar media with ferrous chloride than in media containing no this compound (Table 3). The fastest growth rate was reported for F. culmo- 


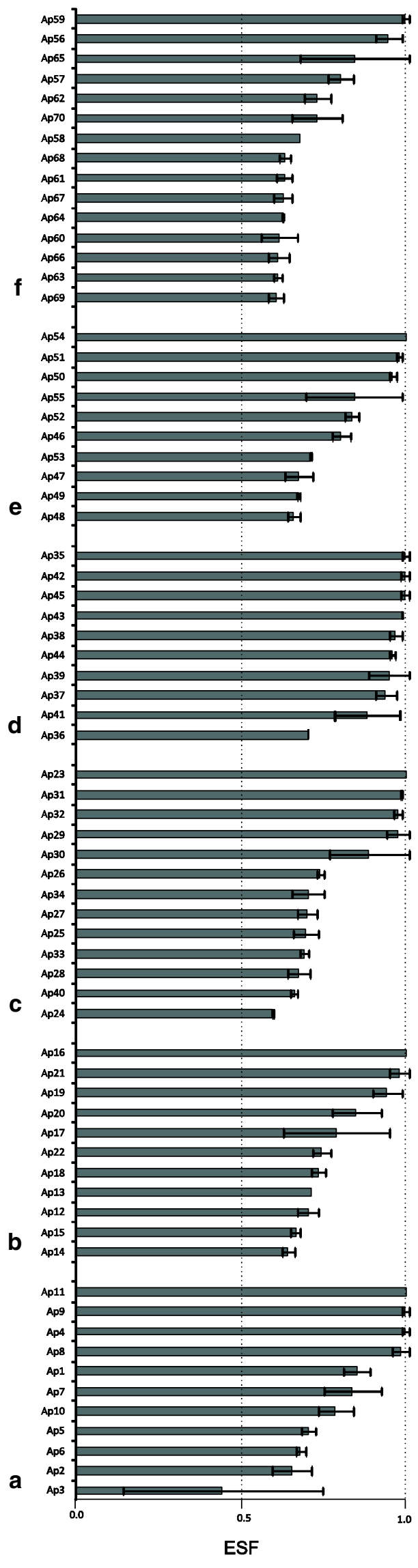

Fig. 1 Biocontrol activity of A. pullulans epiphytic isolates (Ap1Ap70) against $R$. cerealis colony growth expressed in values of elliptical shape factor (ESF). Error bars represent SE. Origin of isolates: A-Amistar 250SC, B-Mirage 450 EC, C-Siarkol Extra $80 \mathrm{WP}$, D-Karben 500 SC, E-Bumper 250 EC

rum colonies cultured in media containing $500 \mu \mathrm{M}$ ferrous chloride. After six days of incubation, the surface area of $F$. culmorum colonies was $45 \%$ larger than the surface area of respective control colonies. The fast growing species $R$. cerealis developed most rapidly in PDA containing $100 \mu \mathrm{M}$ ferrous chloride, and the surface area of its colonies was significantly larger than in PDA without ferrous chloride.

The protective effect of the studied A. pullulans isolate against $F$. culmorum infections was analyzed using seedlings of winter wheat cv. Roma and Sakwa. A series of experiments performed in a growth chamber revealed no significant differences in infection rates of seedlings of booth cultivars (Fig. 2). Seedlings of cv. Roma treated with A. pullulans cell suspensions and inoculated with $F$. culmorum after 96 hours were significantly less severely infected than control, unprotected seedlings inoculated with the pathogen. The protective effect of $A$. pullulans on wheat seedlings of cv. Roma was significant only at the longest time interval. Wheat seedlings of cv. Sakwa were significantly less severely infected than unprotected seedlings inoculated with $F$. culmorum at 24-h and 96-h time intervals between the application of $A$. pullulans cell suspensions and inoculation with $F$. culmorum. Seedlings of cv. Sakwa, compared with cv. Roma, responded faster to inoculation with $F$. culmorum following the application of A. pullulans cells onto the leaves.

\section{Discussion}

Biological control strategies for wheat diseases have been extensively studied. The most commonly tested biologically active microorganisms are bacteria (Jochum et al. 2006; Kita et al. 2004; Nourozian et al. 2006; Liu et al. 2011; Wachowska et al. 2013) and filamentous fungi of the genera Trichoderma (Brožová 2004; Brunner et al. 2005) and Gliocladium (Teperi et al. 1998; Roberti et al. 2008). The activity of epiphytic yeast and yeast-like fungi against cereal phytopathogens remains poorly investigated (Raacke et al. 2006; Wachowska et al. 2003; Zhang et al. 2007), although they abundantly colonize grain crops (Bashi and Fokkema 1977; Dik et al. 1992).

In our study in vitro tests indicate that yeasts fungi can considerably inhibit the growth of the causal agents of stem base diseases. Antibiotic and/or lytic substances produced by the tested isolates of yeasts fungi diffused into the medium and affected the shape of pathogen colonies. In the present experiment, $A$. pullulans exhibited higher activity than $S$. roseus under in vitro conditions. The inhibitory 
Table 3 Inhibition of pathogen radial growth in dual cultures with A. pullulans at different concentrations of iron expressed as area of colonies (in $\left.\mathrm{cm}^{2}\right)$. SE is given in brackets

\begin{tabular}{llllll}
\hline $\begin{array}{l}\text { Concentrations of } \\
\text { iron (ferric chloride } \\
\text { in M) }\end{array}$ & G. graminis & F. culmorum & R. cerealis & H. herpotrichoides & Mean \\
\hline 0 & & & & \\
& $6.46^{\text {bc }}$ & $9.13^{c-g}$ & $7.89^{\text {cde }}$ & $7.35^{\text {cde }}$ & $7.71^{\mathrm{A}}$ \\
10 & $( \pm 0.13)$ & $( \pm 0.26)$ & $( \pm 0.51)$ & $( \pm 0.13)$ & $( \pm 1.34)$ \\
& $5.84^{b}$ & $9.65^{d-g}$ & $9.46^{d-g}$ & $7.58^{c d e}$ & $8.13^{\mathrm{B}}$ \\
100 & $( \pm 0.02)$ & $( \pm 0.11)$ & $( \pm 0.77)$ & $( \pm 0.22)$ & $( \pm 0.26)$ \\
& $6.91^{\text {cde }}$ & $11.53^{g h}$ & $11.32^{\text {fgh }}$ & $( \pm 1.26)$ & $\left( \pm .96^{\mathrm{C}}\right.$ \\
500 & $( \pm 0.12)$ & $( \pm 0.17)$ & $( \pm 0.82)$ & $8.11^{c-f}$ & $9.57^{\mathrm{C}}$ \\
& $6.88^{\text {cde }}$ & $13.24^{h}$ & $10.06^{\text {efg }}$ & $( \pm 0,31)$ & $( \pm 0.22)$ \\
Mean & $( \pm 0.31)$ & $( \pm 0.99)$ & $( \pm 0.96)$ & $8.28^{y}$ & $( \pm 0.01)$ \\
\end{tabular}

Values followed by the same letter do not differ significantly according to SNK test at $p<0.05$ : $a$ - $g$ - for interaction, $w$ - $z$ - for mean values for antagonistic species, $A-C$ - for mean values for $\mathrm{FeCl}_{3}$ concentrations

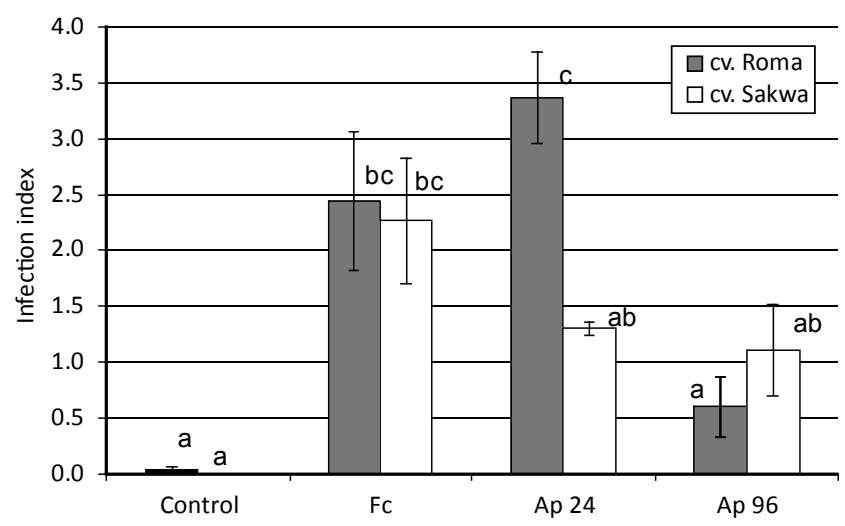

Fig. 2 Susceptibility of winter wheat seedlings of cvs. Sakwa and Roma treated with A. pullulans to infection caused by F. culmorum. Values followed by the same letter do not differ significantly according to SNK test at $p<0.05$. C - untreated control, Fc - control with F. culmorum, Ap 24, Ap 96-24, 96- $\mathrm{h}$ time intervals between the application of A. pullulans cell suspensions and inoculation with F. culmorum. Error bars represent SE

effects of yeasts fungi have been also observed in previous research (Marquina et al. 2002; Walker et al. 1995; Vero et al. 2009). The studies of other authors have shown that $A$. pullulans isolates may produce the enzymes glucanase and chitinase in the presence of Penicillium expansum cell walls (Vero et al. 2009).

In our experiment, the $A$. pullulans isolate obtained from winter wheat grain inhibited the growth of all analyzed pathogens under low iron availability. In a study by Chi et al. (2013), the marine-derived A. pullulans HN 6.2 isolate grown in a medium without added $\mathrm{Fe}^{3+}$ produced hydroxamate-type siderophores at $92.1 \mathrm{mg}$ per g of cell dry weight, and when iron was added to the medium, the production of siderophores dropped to $28 \mathrm{mg}$. The available literature provides no information on the production of siderophores by $A$. pullulans isolates obtained from the growing environ- ment of crop plants. Apart from antibiosis and competition, empirical evidence suggests that $A$. pullulans and other saprotrophs can induce defense mechanisms in plants (Ippolito et al. 2000; Droby et al. 2002; Gary and Goldmann 2004; Raacke et al. 2006; Wees et al. 2008). A few studies have demonstrated that iron levels in the environment can modify fungal pathogenicity, and that reactive ferric iron mediates defensive $\mathrm{H}_{2} \mathrm{O}_{2}$ production in plants (Greenshields et al. 2007).

In our study, $A$. pullulans cells were applied onto the leaves of wheat plants, and the coleoptyles were inoculated with $F$. culmorum. It was found that the tested A. pullulans isolate protected wheat seedlings against infection. The antagonist and the pathogen were spatially separated during the course of the experiment. Seedlings inoculated with the pathogen $24 \mathrm{~h}$ after treatment with the antagonist yeast-like fungus were severely infected, and the noted infection rates were comparable with those reported for the control treatment. The lowest infection rates were observed in seedlings treated with the antagonist cell suspension 96 hours before the inoculation with F. culmorum. Our results corroborate the finding of authors who found that biological methods require longer time intervals between the application of the antagonist and the pathogen (Ippolito et al. 2000; Ghaouth et al. 2002; Zhang et al. 2007). The above phenomenon has been well documented. In studies investigating the induction of defense responses in apple fruit (Ippolito et al. 2000; Ghaouth et al. 2002), the highest activity levels of chitinase and glucanase were noted after 96 hours. The yeast-like fungus $A$. pullulans also provided more effective control of Botrytis cinerea storage rots on fruits after longer time intervals (Ippolito et al. 2000). Yao and Tian (2005) applied the antagonist Cryptococcus laurentii to control postharvest diseases (Monilinia fructicola and Penillium expansum) in peach fruit. The cited authors noted the maximum activity levels of 1,3-glucanase and peroxidase (POD) and enhanced 
activity of phenylalanine ammonia-lyase (PAL) after 24 hours at $25^{\circ} \mathrm{C}$. Resistance induction in plants treated with non-pathogenic microorganisms has been observed in cereals (Roberti et al. 2008; Jochum et al. 2006; Zhang et al. 2007) and stored fruits (Ippolito et al. 2000; Ghaouth et al. 2002; Droby et al. 2002; Yao and Tian 2005).

In our study, seedlings of two wheat cultivars showed different susceptibility to $F$. culmorum infection, which confirms that proper cultivar selection is an important consideration in organic and integrated farming systems where the use of chemical crop protection agents is limited. The defense responses of different plant varieties have been widely discussed in literature. Westhuizen et al. (1998), who studied the defense responses of several wheat cultivars to aphid infestation, found that peroxidase activity increased in resistant varieties after 2 days. A rapid increase in chitinase activity levels was also observed in some resistant wheat varieties as soon as after 1 day. In susceptible cultivars, peroxidase activity did not increase or increased slightly within a few days. An increase in chitinase activity in the tissues of susceptible wheat cultivars was observed after 6-12 days, depending on cultivars, and it was substantially lower than in the resistant cultivars. In a study by Mohammadi and Kazemi (2002), peroxidase and polyphenol oxidase activities were higher in resistant non-inoculated winter wheat cultivars, compared with susceptible cultivars. The activity levels of the above compounds increased also after wheat head inoculation with the pathogen Fusarium graminearum, particularly in resistant cultivars. Wiwart et al. (2013) investigated the response of three wheat species to head inoculation with F. culmorum and reported that the protein content of grain derived from inoculated heads was on average $7.64 \%$ higher, compared with control grain. Raacke et al. (2006) studied the expression of systemic acquired resistance-related genes in Arabidopsis and reported that plant treatment with an autoclaved yeast suspension activated the salicylate pathway and induced the accumulation of camalexin. Salicylic acid and jasmonic acid pathways were differently activated by bacterial peptide flagellins. The activation of defense mechanisms involving no camalexin accumulation was observed in Arabidopsis by GomezGomez et al. (1999).

The results of our study indicate that the A. pullulans var. pullulans Ap 6 isolate obtained from winter wheat grain inhibits the growth of stem base pathogens and protects winter wheat seedlings against $F$. culmorum. A. pullulans exerts varied and long-term effects on pathogens and crop plants, including the production of compounds that suppress pathogen growth, compete for iron with pathogens and modify plant susceptibility to infections. However, the numerous disadvantages of the presented method include different responses of cultivars to the applied biocontrol agent, and a strong correlation between biocontrol efficacy and the time of application of the fungal antagonist.

Acknowledgements This experiment was partially financed by the National Science Center, Poland, project No. N N 310116638.

Open Access This article is distributed under the terms of the Creative Commons Attribution License which permits any use, distribution, and reproduction in any medium, provided the original author(s) and the source are credited.

\section{References}

Barnett JA, Payne RW, Yarrow D (2000) Yeasts: characteristics and identification. Cambridge University Press. United Kingdom, $1139 \mathrm{pp}$

Bashi E, Fokkema NJ (1977) Environmental factors limiting growth of Sporobolomyces roseus, an antagonist of Cochliobolus sativus on wheat leaves. T Brit Mycol Soc 68:17-25

Bateman GL, Nicholls PH, Chamberlain K (2006) The effectiveness of eleven sterol biosynthesis-inhibiting fungicides against the takeall fungus, Gaeumannomyces graminis var. tritici, in relation to their physical properties. Pest Manag Sci 29(1):109-122

Brožová J (2004) Mycoparasitic fungi Trichoderma spp. in plant protection. Plant Protect Sci 40(2):63-74

Brunner K, Zeilinger K, Cielionto R, Woo SL, Lorito M, Kubicek CP, Mach RL (2005) Improvement of the fungal biocontrol agent Trichoderma atroviride to enhance both antagonism and induction of plant systemic disease resistance. Appl Environ Microb 71(7):3959-3965

Chi Z, Wang XX, Geng Q, Chi ZM (2013) Role of a GATA-type transcriptional repressor Sre1 in regulation of siderophore biosynthesis in the marine-derived Aureobasidium pullulans HN6.2. Biometals 26:955-967

Dik AJ., Fokkema NJ., van Pelt JA (1992) Influence of climatic and nutrition factors on yeast population dynamics in the phyllosphere of wheat. Microb Ecol 23:41-52

Droby S, Vinokur V, Weiss B, Cohen L, Daus A, Goldschmidt EE, Porat R (2002) Induction of resistance to Penicillium digitatum in grapefruit by the yeast biocontrol agent Candida oleophila. Phythopath 92(4):393-399

Druefors UA, Schnürer J (2004) Mold-inhibitory activity of different yeast species during airtight storage of wheat grain. FEMS Yeast Res 5:373-378

FRAC (2009) Frac Code list: fungicide sorted by mode of action. FRAC (2009)

Gary EV, Goldmann RM (2004) Systemic acquired resistance and induced systemic resistance in conventional agriculture. Crop Sci 44:1920-1934

Gaur R, Singh R, Gupta M, Kumar M, Gaur MK (2010) Aureobasidium pullulans, an economically important polymorphic yeast with special reference to pullulan. Afr J Biotechnol 9(47):7989-7997

Ghaouth AE, Wilson CL, Wisniewski M (2002) Control of postharvest decay on apple fruit with Candida saitoana and induction of defense responses. Phytopath 93(3):345-348

Gomez-Gomez L, Felix G, Boller T (1999) A single locus determines sensitivity to bacterial flagellin in Arabidopsis thaliana. Plant $\mathbf{J}$ 18(3):277-284

Greenshields DL, Liu G, Wei Y (2007) Roles of iron in plant defense and fungal virulence. Plant Signal Behav 2(4):300-302

Hoagland DR Arnon DI (1950) The water-culture method for growing plants without soil. Circ. 347. Univ. of Calif. Agric. Exp. Station, Berkley 
Holb IJ, Kunz S (2013) Integrated control of brown rot blossom blight by combining approved chemical control options with Aureobasidium pullulans in organic cherry production. Crop Prot 54:114-120

Ikai K, Takesako K, Mizutami S, Yamamoto J, Ogawa Y, Endo M (1991) Structure of aureobasidins A to R. J Antibiot 44:1187-1198

Ippolito A, El Ghaouth A, Wilson C L, Wisniewski M (2000) Control of postharvest decay of apple fruit by Aureobasidium pullulans and induction of defense responses. Postharvest Biol Tec 19:265-272

Jochum CC, Osborne LE, Yuen GY (2006) Fusarium head blight biological control with Lysobacter enzymogenes strain C3. Biol Control 39:336-344

Kita W, Pietr SJ, Nowak W, Sowiński J (2004) The effect of biological and conventional method of plant protection on the field and healthiness of two wheat cultivars (in Polish). Annales UMCS, Sec. E 59(4):1747-1754

Kurtzman CP, Fell JW, Boekhout T (2011) The yeasts a taxonomic study. Elsevier, London, pp 2080

List of Agriculture Cultivars (2008) Research center for cultivar testing. Stupia Wielka, Poland

Liu B, Huang L, Kang Z, Buchenauer H (2011) Evaluation of endophytic bacterial strains as antagonists of take-all in wheat caused by Gaeumannomyces graminis var. tritici in greenhouse and field. J Pest Sci 84:257-264

Maliński ZT (2008) Studies on in vitro activity of picoxystrobin and its mixtures with other fungicides against Ramulispora herpotrichoides and Ramulispora acuformis. Pestycydy 1-2:75-86

Marquina D, Santos A, Peinado JM (2002) Biology of killer yeasts. Int Microbiol 5:65-71

Martin JP (1950) Use of acid, rose Bengal and streptomycyn in the plate method for estimating soil fungi. Soil Sci 38:215-220

Mohammadi M, Kazemi H (2002) Changes in peroxidase and polyphenol oxidase activites in susceptible and resistant wheat heads inoculated with Fusarium graminearum. Plant Sci 162:491-498

Nourozian J, Etebarian HR, Khodakaramian G (2006) Biological control of Fusarium graminearum on wheat by antagonistic bacteria. Songklanakarin J Sci Techn 28(Suppl. 1):29-38

Philpott CC (2006) Iron uptake in fungi: a system for every source. Biochim Biophys Acta 1763:636-645.

Prasongsuk S, Ployngam S, Wacharasindhu S, Lotrakul P, Punnapayak H (2013) Effects of sugar and amino acid supplementation on $A u$ reobasidium pullulans NRRL 58536 antifungal activity against four Aspergillus species. Appl Microbiol Biot 97:7821-7830

Raacke IC., von Rad U, Mueller MJ, Berger S (2006) Yeast increases resistance in Arabidopsis against Pseudomonas syringae and Botrytis cinerea by salicylic acid-depemdent as well as- independent mechanisms. Mol Plant Microbe Interact 19(10):1138-1146

Rasband WS (1997-2011) ImageJ US. National Institutes of Health, Bethesda, Maryland, USA. http://imagej.nih.gov/ij/. Accessed 02 May 2014

Raspor P, Miklič-Milek D, Avbelj M, Čadež N (2010) Biocontrol of grey mould disease on grape caused by Botrytis cinerea with autochthonous wine yeasts. Food Technol Biotech 48(3)336-343

Ray RV, Crook MJ, Jenkinson P, Edwards SG (2006) Effect of eyespot caused by Oculimacula yallundae and $O$. acuformis visually and by competitive PCR, on stem strength associated with lodging resistance and yield of winter wheat. J Exp Bot 57(10):2249-2257
Roberti R, Veronesi AR, Cesari A, Cascone A, Berardino ID, Bertini L, Caruso C (2008) Induction of PR proteins and resistance by the biocontrol agent Clonostachys rosea in wheat plants infected with Fusarium culmorum. Plant Sci 175:339-347

Schena L, Nigro F, Pentimone I, Ligorio A, Ippolito A (2003) Control of postharvest rots of sweet cherries and table grapes with endophytic isolates of Aureobasidium pullulans. Postharvest Biol Tec 30:209-220

StatSoft, Inc. (2009) STATISTICA (data analysis software system), version 9. www.statsoft.com. Accessed 02 May 2014

Teperi E, Keskinen M, Ketoja E, Tahvonen R (1998) Screening for fungal antagonists of seed-borne Fusarium culmorum on wheat using in vivo tests. Eur J Plant Pathol 104:243-251

Vero S, Garmendia G, González MB, Garat MF, Wisniewski M (2009) Aureobasidium pullulans as a biocontrol agent of postharvest pathogens of apples in Uruguay. Biocontrol Sci Techn 19(9/10):1033-1049

Wachowska U, Majchrzak B, Borawska M, Karpińska Z (2003) Biological control of winter wheat pathogens by bacteria. Acta fytot Zoot 7:345-348

Wachowska U, Kucharska K, Jędryczka M, Łobik N (2013) Microorganisms as biological control agents against Fusarium pathogens in winter wheat. Polish J Environ Stud 22(2):591-597

Walker GM, McLeod AH, Hodgson VJ (1995) Interactions between killer yeasts and pathogenic fungi. FEMS Microbiol Lett 127:213-222

Wang W, Chi Z, Liu G, Buzdar MA, Chi Z, Gu Q (2009) Chemical and biological characterization of siderophore produced by the marinederived Aureobasidium pullulans HN6.2 and its antibacterial activity. Biometals 22(6):965-72

Wees SCM, Sjoerd VE., Pieterse CMJ (2008) Plant immune responses triggered by beneficial microbes. Curr Opin Plant Biol 11:443-448

Westhuizen AJ, Qian XM, Botha AM (1998) Differential induction of apoplastic peroxidase and chitinase activities in susceptible and resistant wheat cultivars by Russian wheat aphid infestation. Plant Cell Rep 18:132-137

Wiwart M, Suchowilska E, Kandler W, Sulyok M, Groenwald P, Krska R (2013) Can Polish wheat (Triticum polonicum L.) be an interesting gene source for breeding wheat cultivars with increased resistance to Fusarium head blight? Gen Resour Crop Ev 60(8):2359-2373

Yao HJ, Tian SP (2005) Effects of biocontrol agent and methyl jasmonate on postharvest diseases of peach fruit and the possible mechanisms involved. J Appl Microbiol 98:941-950

Zhang S, Schisler DA, Boem MJ, Slininger PJ (2007) Utilization of chemical inducers of resistance and Cryptococcus flavescens $\mathrm{OH}$ 182.9 to reduce Fusarium head blight under greenhouse condition. Biol Control 42:308-315

Zhong W, Jeffries MW, Nafsika H (2000) Inhibition of Inositol Phosphorylceramide Synthase by Aureobasidin A in Candida and $\mathrm{As}$ pergillus Species. Antimicrob Agents Ch 44(3):651-653 